\title{
Adaptation principles of agriculture to climate change
}

\author{
Peeter Karing, Ain Kallis*, Heino Tooming \\ Estonian Meteorological and Hydrological Institute, Rävala 8, EE-10143 Tallinn, Estonia
}

\begin{abstract}
An analysis of climate change impacts on the level of agricultural production is presented based on long-term experimental data on yields of crops grown in different soils and climatic zones. Mathematical models combining available data on the biology of agricultural crops and their response to climatic conditions have been used. The principle of maximum plant productivity is the basis of this modelling effort. The potential and meteorologically possible yields under existing environmental conditions were calculated using the potato dynamic model POMOD. The analyses were completed under different climate change scenarios. According to the climate change scenarios HADCM 2 and ECHAM 3TR, mean potato yields will increase by about 6 to $8 \%$. The yield increase is larger (10 to $16 \%$ ) on coastal islands and in North Estonia. A new approach and classification of micro-climate geocomplexes was developed. Agricultural production was found to be highly sensitive to micro-climatic variations. The proposed approach permits more objective use of meteorological data in changing climatic conditions. Shifts in agroclimate were established using this modelling approach. The sums of degree-days, particularly above 0 and $5^{\circ} \mathrm{C}$, have significantly risen during the period 1807-1995. The development of potato varieties adapted to a changing climate is possible. A strategy for adaptation of agriculture to climate change is presented.
\end{abstract}

KEY WORDS: Adaptation $\cdot$ Model yields $\cdot$ M icro-climate $\cdot$ Potato $\cdot$ Barley

\section{INTRODUCTION}

The extent and yield of agriculture in high latitude regions is largely determined by thermal parameters (Carter 1996). The potential impacts on agriculture from global climate change have been analysed in qualitative and quantitative terms (Parry et al. 1988, Roostalu et al. 1996, Parry \& Carter 1998). Global climate change is mostly evaluated using the changes of annual average ambient temperature indicators, which bring about regional changes in the climatic regime. Unfortunately, regional climate scenarios are not always consistent with global indicators. Therefore, it is necessary to carry out regionally based quantitative analyses of climate indicators, such as agronomic crop yields.

*Addressee for correspondence.

E-mail: kallis@aai.ee

\section{METHODS AND MATERIALS}

Various indices and complex characteristics have been proposed to evaluate agroclimatic potential (Sepp \& Tooming 1991). Assessment of agroclimatic resource standards or model yields has already been made (Tooming 1977, 1984, 1993, Zhukovsky et al. 1990). The method used is based on the principle of maximum plant productivity. According to this principle, adaptation and succession processes in natural plant communities are achieved under the prevailing environmental conditions (Tooming \& Kallis 1972, Tooming 1977, 1993) and plant or agronomic productivity can be very low (arid and cool zones) or very high (tropical rain forests, water meadows), based on the prevailing environmental conditions. This principle has been applied to solve various problems in plant physiology, ecology, and agriculture. The most remarkable of its ramifications in agriculture is the recommendation that plant cultivation be organised on this basis. 


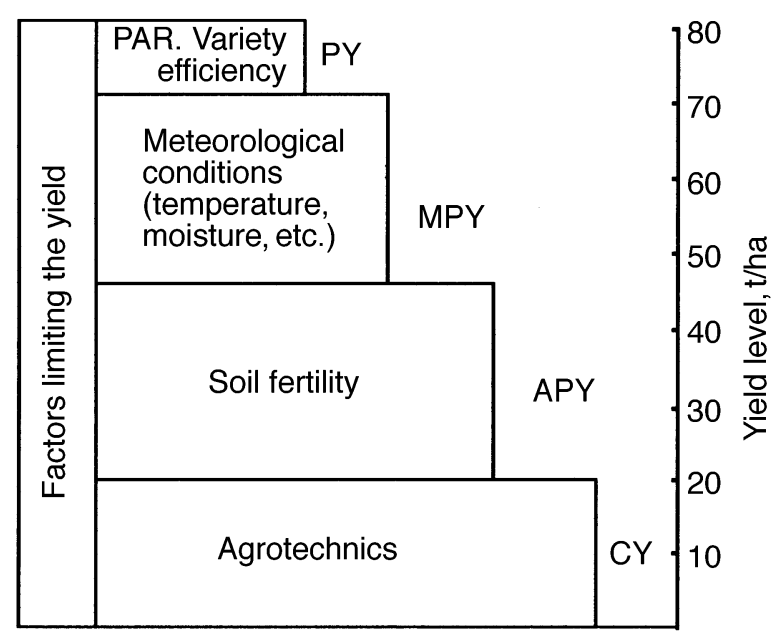

Fig. 1. Levels of model yields and factors limiting the yield of main agricultural crops. PY: potential yields; MPY: meteorologically possible yield; APY: actual possible yield; CY: commercial real yield; PAR: photosynthetically active radiation

The ecologically founded standard yields can be classified as follows (Fig. 1): (1) Potential yield (PY) is the yield under ideal soil and meteorological conditions. PY depends on the biological parameters of species or varieties and the influx of solar radiation. (2) Meteorologically possible yield (M PY) is the maximum yield conceivable under existing meteorological conditions provided there is high soil fertility and supplemental agrotechnology. (3) Actual possible yield (APY) is the maximum yield achievable under the present level of agrotechnology and existing meteorological and soil conditions. (4) The real yield under commercial conditions-CY (yield in the field).

The ecologically founded standard yields PY, MPY, and APY characterize the agroclimatic potential of agriculture. These yields may be calculated using mathematical simulation models with input data on plant growth parameters and meteorological conditions.

Within this modelling framework, the estimation of the agroclimatic potential starts from the theoretically highest yield level in optimal weather conditions (that is, PY). The M PY characterizes the agricultural ecosystem productivity, which is limited above all by the amounts of photosynthetically active radiation, heat, and soil moisture (Fig. 1). The agroclimatic potential of a given region is mainly associated with the mean value of MPY and its statistical distribution across the ecosystems.

Evaluation of agroclimatic resources based on ecological model yields has been used by several scientists in the former Soviet Union and East Europe (Tooming $\&$ Karing 1977). This modelling approach is used to cal- culate possible agronomic yields in different regions. The idea of ecologically founded model yields was developed by de Wit and Penning de Vries (Penning de Vries 1984).

One of the most important agricultural products in Estonia is potatoes. Potato fields constitute about $4 \%$ of all arable land. But mean yields are low, only 13 to $14 \mathrm{Mg} \mathrm{ha}^{-1}$. Therefore, a future task for Estonian agricultural climatologists is the analysis of options for improving potato yield potential. We have previously devised the dynamic model POMOD for simulating potato model yields (Sepp \& Tooming 1991). Using this model and climate change scenarios, we have predicted changes in the potato MPY. To calculate ambient temperature and precipitation change by the year 2050, the GCM models HADCM 2 (Hadley Centre, UK) and ECHAM 3TR (European Centre Hamburg, Germany) have been selected. HADCM 2 represents a moderate global change scenario, and ECHAM 3TR a warm and wet (more extreme global change) scenario (Keevallik 1998). The climatic data employed cover the period 1965-1996. These Estonian climatic data were modified for each scenario. The control case of MPY was calculated using actual data. Optimal sowing and harvesting dates for the calculations of MPY were established from the condition of maximum yield (Kadaja \& Tooming 1998).

\section{RESULTS AND DISCUSSION}

Calculations on the basis of the dynamic model POMOD using previously described methods (Kadaja $\&$ Tooming 1998) show that the climatically possible yield is $55.3 \mathrm{Mg} \mathrm{ha}^{-1}$ for Estonian territory. However, climatic conditions over Estonia are diverse. Within a distance of only 200 to $300 \mathrm{~km}$, sharp contrasts occur in ambient precipitation, solar radiation, and soil moisture storage due to the transition from semi-continental inland to maritime coastal and island areas. MPY is lower in coastal zones and on coastal islands and higher in inland areas and South Estonia (Fig. 2). Potato yield increases ranged from $3 \%$ for the moderate to $17 \%$ for the extreme scenario.

For different climatic zones of Estonia, M PY changes with scenario. The increase in potato yields due to climate change is highest on the islands in Hiiu and Saare zones and in North Estonia, where the relative increase in yield ranges from 10 to $16 \%$. In South Estonia, small increases in yield were observed in both scenarios. Actual yields, based on MPY, are higher in the southern part of Estonia. Based on future scenarios, optimum potato production conditions shift to N orth Estonia.

Besides changes in average yields, changes in yield variability also are of great importance. The variability 


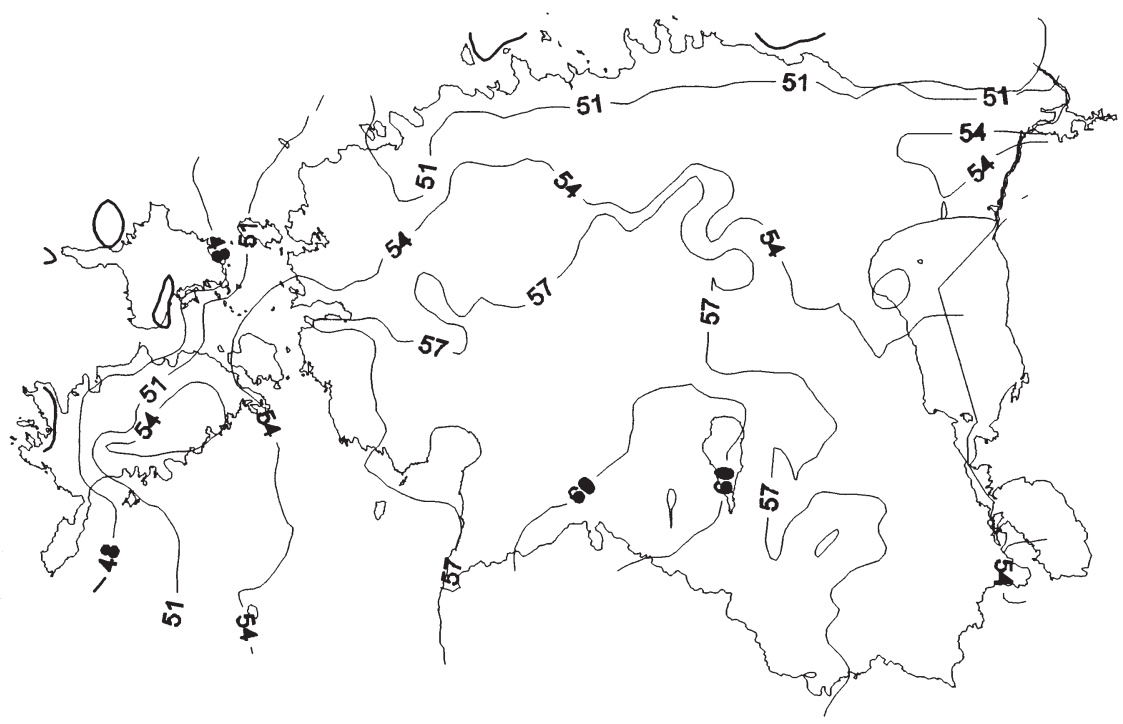

Fig. 2. M eteorologically possible yield (MPY) in $\mathrm{Mg} \mathrm{ha}^{-1}$ in Estonia between 1965 and 1996

of yields may be described by cumulative statistical distributions. All the curves are normalized in relation to the average M PY over the period 1965-1996. It was found (Kadaja \& Tooming 1998) that, in both scenarios, low and medium scenario changes result in the greatest difference from the real data near the mean values of the yields, while changes in low and high yields are less pronounced (Fig. 3). Large changes in climate will cause a more substantial decrease in high and low yields in both scenarios.

\subsection{Efficiency of the micro-climatic approach}

To characterize micro-climatic variability of smaller areas, a classification of geo-complexes according to their influence on the micro-climate has been developed (Table 1) (Karing 1992). It has been found that the micro-climatic variations in water resources in Southeast Estonia are significant, and the best microclimatic conditions for grassland production are found on the tops of hills and in the valleys between them. In the case of barley cultivation, favourable moisture conditions prevail on the lower parts of south-facing slopes and in flat areas with loamy soils. The yield differences between the foot of north-facing slopes and the lower part of south-facing slopes are as high as $50 \%$.

As a detailed example, calculations using a simple model were made to estimate the efficiency of regulating the water regime of soils under different microclimatic conditions on a state farm situated in a hilly landscape area in one meso-climate district in Estonia (Karing 1995). The calculations were carried out for 3 levels of barley crop production $\left(Y_{\theta}\right)$ : (1) $Y_{\theta}=9.3 \mathrm{Mg}$ $\mathrm{ha}^{-1}$, meso-climatic potential of barley crop yield; (2) $\mathrm{Y}_{\theta}$ $=3.8 \mathrm{Mg} \mathrm{ha}^{-1}$, serving as the indicator of barley yields in the conditions where socio-economic factors are pre-

\section{MODERATE SCENARIOS}

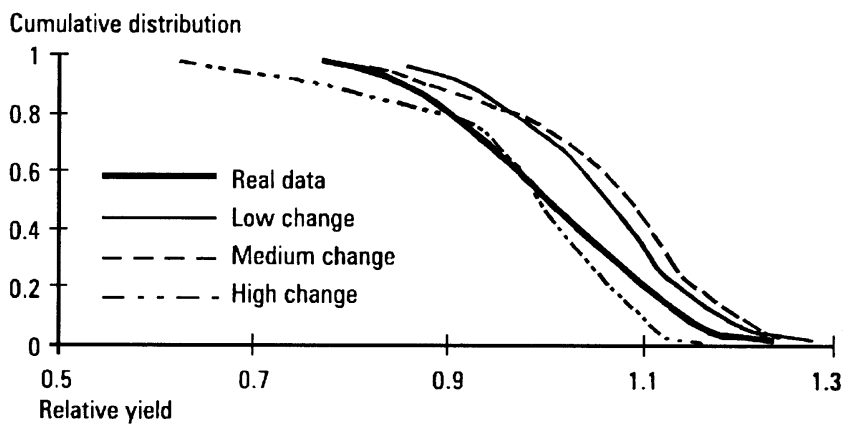

\section{WARM AND WET SCENARIOS}

Cumulative distribution

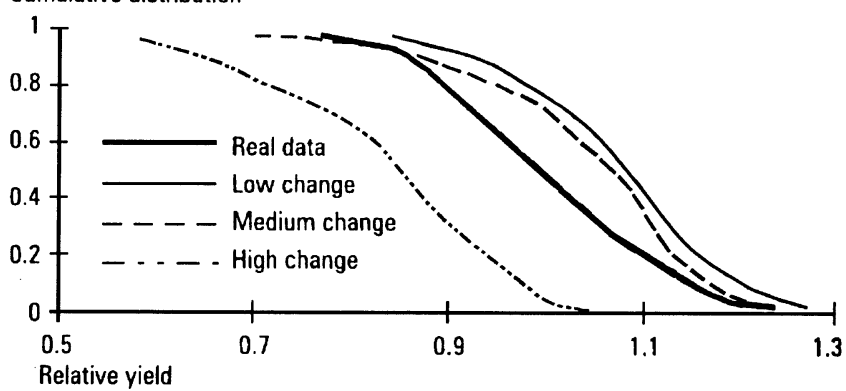

Fig. 3. Cumulative distribution of relative potato MPY computed according to the different climatic scenarios and averaged over the Estonian territory 
dominant; and (3) $Y_{\theta}=1.0 \mathrm{Mg} \mathrm{ha}^{-1}$, barley crop yield with the naturally available nutrients (without mineral fertilizers). The results are presented in Table 2.

Table 1 and Fig. 4 use the results presented in Table 2 for given parts of the slopes and landscapes (for example, for the area presented in Fig. 4). The efficiency of manipulating micro-climate varies greatly in different localities (Table 2). Under the average level of barley yields, optimization of the water regime of the soil will raise the barley yield by $1.4 \mathrm{Mg} \mathrm{ha}^{-1}$. Both irrigation and drainage will be needed. Raising the level of land cultivation increases the efficiency of microclimate manipulation. In the case of a meso-climatic potential of $9.3 \mathrm{M} \mathrm{g} \mathrm{ha}^{-1}$ under average yearly climatic conditions, the efficiency of regulating the water regime can be expressed as a yield increase of more than $3 \mathrm{Mg} \mathrm{ha}^{-1}$ (Table 2).

It is advisable to arrange all plots into various groups based on the relative variability of barley yields due to the micro-climate and soil climate. Group I might include the lower parts of southern slopes, drained loams in lowlands, and old arable land in flat places. Group II would then include the upper and middle parts of northern slopes and sandy loams in flat areas. Group III would include the foot of southern slopes and temporarily excessively wet and drained sandy loams in the lowlands. Group IV might include hilltops, lower parts of northern slopes, and middle parts of southern slopes.

It was found that the efficiency of fertilizers depends notably on the level of yields (Fig. 5). If the yield level is

Table 1. Classification of geo-complexes according to their influence on the micro-climate

\begin{tabular}{|c|c|c|c|c|c|c|c|}
\hline $\begin{array}{l}\text { Relief } \\
1\end{array}$ & $\begin{array}{c}\text { Incline } \\
2\end{array}$ & $\begin{array}{c}\text { Part of slope } \\
3\end{array}$ & $\begin{array}{c}\text { Properties of soil } \\
4\end{array}$ & & & & \\
\hline \multirow[t]{2}{*}{ Top } & $\begin{array}{l}\text { Slope is below } \\
2-12^{\circ}\end{array}$ & & $\begin{array}{l}\text { Sand } \\
\text { Sandy loam } \\
\text { Sandy clay }\end{array}$ & $\begin{array}{l}1 \\
2 \\
3\end{array}$ & & & \\
\hline & $\begin{array}{l}\text { Slope below is } \\
\text { over } 12^{\circ}\end{array}$ & & $\begin{array}{l}\text { Sand } \\
\text { Sandy loam } \\
\text { Sandy clay }\end{array}$ & $\begin{array}{l}4 \\
5 \\
6\end{array}$ & & & \\
\hline \multirow[t]{7}{*}{ Slopes } & $2-12^{\circ}$ & & & Northern & Southern & Eastern & Western \\
\hline & & $\begin{array}{l}\text { Upper } \\
\text { Middle } \\
\text { Lower } \\
\text { Foot }\end{array}$ & Sand & $\begin{array}{r}7 \\
8 \\
9 \\
10\end{array}$ & $\begin{array}{l}31 \\
32 \\
33 \\
34\end{array}$ & $\begin{array}{l}55 \\
56 \\
57 \\
58\end{array}$ & $\begin{array}{l}79 \\
80 \\
81 \\
82\end{array}$ \\
\hline & & $\begin{array}{l}\text { Upper } \\
\text { Middle } \\
\text { Lower } \\
\text { Foot }\end{array}$ & Sandy loam & $\begin{array}{l}11 \\
12 \\
13 \\
14\end{array}$ & $\begin{array}{l}35 \\
36 \\
37 \\
38\end{array}$ & $\begin{array}{l}59 \\
60 \\
61 \\
62\end{array}$ & $\begin{array}{l}83 \\
84 \\
85 \\
86\end{array}$ \\
\hline & & $\begin{array}{l}\text { Upper } \\
\text { Middle } \\
\text { Lower } \\
\text { Foot }\end{array}$ & Sandy clay & $\begin{array}{l}15 \\
16 \\
17 \\
18\end{array}$ & $\begin{array}{l}39 \\
40 \\
41 \\
42\end{array}$ & $\begin{array}{l}63 \\
64 \\
65 \\
66\end{array}$ & $\begin{array}{l}87 \\
88 \\
89 \\
90\end{array}$ \\
\hline & Over $12^{\circ}$ & $\begin{array}{l}\text { Upper } \\
\text { Middle } \\
\text { Lower } \\
\text { Foot }\end{array}$ & Sand & $\begin{array}{l}19 \\
20 \\
21 \\
22\end{array}$ & $\begin{array}{l}43 \\
44 \\
45 \\
46\end{array}$ & $\begin{array}{l}67 \\
68 \\
69 \\
70\end{array}$ & $\begin{array}{l}91 \\
92 \\
93 \\
94\end{array}$ \\
\hline & & $\begin{array}{l}\text { Upper } \\
\text { Middle } \\
\text { Lower } \\
\text { Foot }\end{array}$ & Sandy loam & $\begin{array}{l}23 \\
24 \\
25 \\
26\end{array}$ & $\begin{array}{l}47 \\
48 \\
49 \\
50\end{array}$ & $\begin{array}{l}71 \\
72 \\
73 \\
74\end{array}$ & $\begin{array}{l}95 \\
96 \\
97 \\
98\end{array}$ \\
\hline & & $\begin{array}{l}\text { Upper } \\
\text { Middle } \\
\text { Lower } \\
\text { Foot }\end{array}$ & Sandy clay & $\begin{array}{l}27 \\
28 \\
29 \\
30\end{array}$ & $\begin{array}{l}51 \\
52 \\
53 \\
54\end{array}$ & $\begin{array}{l}75 \\
76 \\
77 \\
78\end{array}$ & $\begin{array}{r}99 \\
100 \\
101 \\
102\end{array}$ \\
\hline $\begin{array}{l}\text { Plain between } \\
\text { hills }\end{array}$ & & & $\begin{array}{l}\text { Sand } \\
\text { Sandy loam } \\
\text { Sandy clay } \\
\text { Loams } \\
\text { Peat and excessively } \\
\text { moist mineral soil }\end{array}$ & $\begin{array}{l}103 \\
104 \\
105 \\
106 \\
107\end{array}$ & & & \\
\hline
\end{tabular}


Table 2. Agroclimate indicators of the water regime regulation efficiency of soils of barley crops under different micro-climate conditions. $\Delta E$ : change in soil moisture $(\mathrm{mm})$-irrigation or drainage; $Y_{\theta}$ : level of barley crop production; $Y_{A}$ and $Y_{B}$ : yield levels after and before water regime regulation; $\Delta \mathrm{Y}$ : yield growth rate

\begin{tabular}{|c|c|c|c|c|c|c|c|c|c|c|}
\hline \multirow[t]{2}{*}{ Position } & \multirow[t]{2}{*}{$\Delta \mathrm{E}$} & \multicolumn{3}{|c|}{$\mathrm{Y}_{\theta}=3.8 \mathrm{Mg} \mathrm{ha}^{-1}$} & \multicolumn{3}{|c|}{$Y_{\theta}=9.3 \mathrm{Mg} \mathrm{ha}^{-1}$} & \multicolumn{3}{|c|}{$Y_{\theta}=1.0 \mathrm{Mg} \mathrm{ha}^{-1}$} \\
\hline & & $\mathrm{Y}_{\mathrm{A}}$ & $\mathrm{Y}_{\mathrm{B}}$ & $\Delta \mathrm{Y}$ & $\mathrm{Y}_{\mathrm{A}}$ & $\mathrm{Y}_{\mathrm{B}}$ & $\Delta \mathrm{Y}$ & $\mathrm{Y}_{\mathrm{A}}$ & $Y_{B}$ & $\Delta \mathrm{Y}$ \\
\hline Hilltop & 59 & 3.8 & 2.5 & 1.3 & 9.3 & 6.0 & 3.3 & 1.0 & 0.6 & 0.4 \\
\hline \multicolumn{11}{|l|}{ Northern slope } \\
\hline Upper part & 0 & 3.4 & 3.4 & 0 & 8.7 & 8.7 & 0 & 1.0 & 1.0 & 0 \\
\hline Middle part & 0 & 3.3 & 3.3 & 0 & 8.2 & 8.2 & 0 & 1.0 & 1.0 & 0 \\
\hline Lower part & -46 & 3.3 & 2.4 & 0.9 & 8.2 & 6.0 & 2.2 & 1.0 & 0.6 & 0.4 \\
\hline Foot & -71 & 3.2 & 1.8 & 1.4 & 8.0 & 4.6 & 3.4 & 1.0 & 0.5 & 0.5 \\
\hline \multicolumn{11}{|l|}{ Southern slope } \\
\hline Upper part & 57 & 3.8 & 2.5 & 1.3 & 9.5 & 6.3 & 3.2 & 1.0 & 0.7 & 0.3 \\
\hline Middle part & 49 & 3.8 & 2.7 & 1.1 & 9.4 & 6.7 & 1.7 & 1.0 & 0.7 & 0.3 \\
\hline Lower part & 0 & 3.8 & 3.8 & 0 & 9.4 & 9.4 & 0 & 1.0 & 1.0 & 0 \\
\hline Foot & -39 & 3.7 & 2.8 & 0.9 & 9.2 & 7.1 & 2.1 & 1.0 & 0.8 & 0.2 \\
\hline \multicolumn{11}{|l|}{ Lowland } \\
\hline Temporary excessive moisture & -30 & 3.5 & 2.9 & 0.6 & 8.6 & 7.0 & 1.6 & 0.9 & 0.8 & 0.1 \\
\hline Drained loams & 25 & 3.5 & 3.0 & 0.5 & 8.6 & 7.3 & 1.6 & 0.9 & 0.8 & 0.1 \\
\hline Drained sandy loams & 0 & 3.5 & 3.5 & 0 & 8.6 & 8.6 & 0 & 0.9 & 0.9 & 0 \\
\hline Loams & 17 & 3.7 & 3.3 & 0.4 & 9.0 & 8.1 & 0.9 & 1.0 & 0.9 & 0.1 \\
\hline Sandy loams & 0 & 3.7 & 3.7 & 0 & 9.9 & 9.0 & 0 & 1.0 & 0.9 & 0 \\
\hline
\end{tabular}

Fig. 4. Micro-climatic map of the territorial distribution of elementary micro-climate areas (geo-complex codes are given in Table 1)

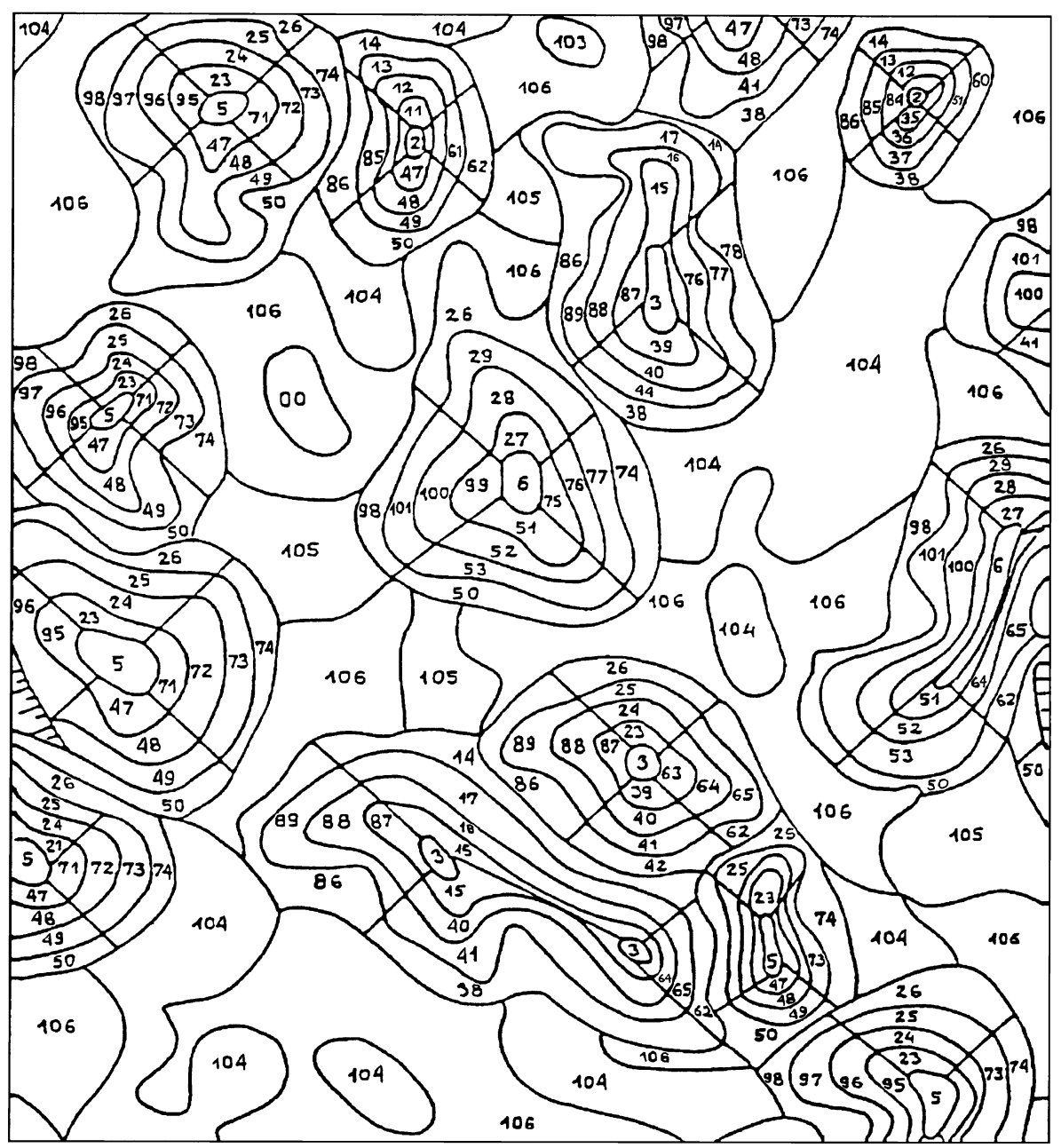




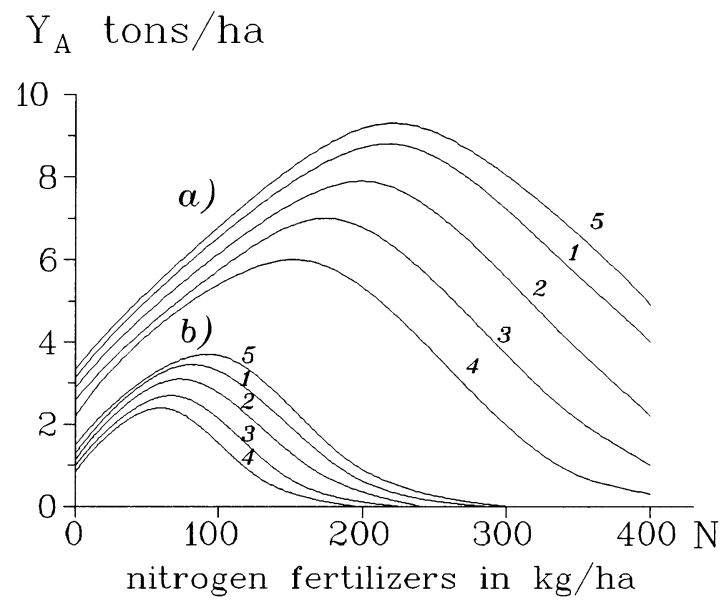

Fig. 5. Dependence of barley yields $\left(Y_{A}\right)$ on the quantity of nitrogen fertilizers under various conditions of micro-climate and soil climate in the case of a maximum yield of (a) 9.3 and (b) $3.8 \mathrm{Mg} \mathrm{ha}^{-1}$ (1-4 = numbers of locational Groups I to IV; $5=$ background indicator)

3.8 $\mathrm{Mg} \mathrm{ha}^{-1}$ or below, the growth of yields due to additional quantities of nitrogen is independent of the type of micro-climate up to $60 \mathrm{~kg} \mathrm{ha}^{-1}$, and up to $100 \mathrm{~kg} \mathrm{ha}^{-1}$ for a maximum yield level of $9.3 \mathrm{Mg} \mathrm{ha}^{-1}$. If fertilizer doses are increased beyond the amount demanded by plants, they will have a negative effect on yields.

The efficiency of manipulation with micro-climate depends notably on the level of land cultivation of a particular farm, as well as the doses of mineral fertilizers applied. The higher the production level, the higher the efficiency of micro-climate management. Measures of manipulation with micro-climate should always be planned together with improvements in production conditions on the farm. By using the study methods presented here, potential and real opportunities in crop cultivation can be identified and ultimately implemented. M ore radical measures available for uti-

\section{Air temperature ${ }^{\circ} \mathrm{C}$}

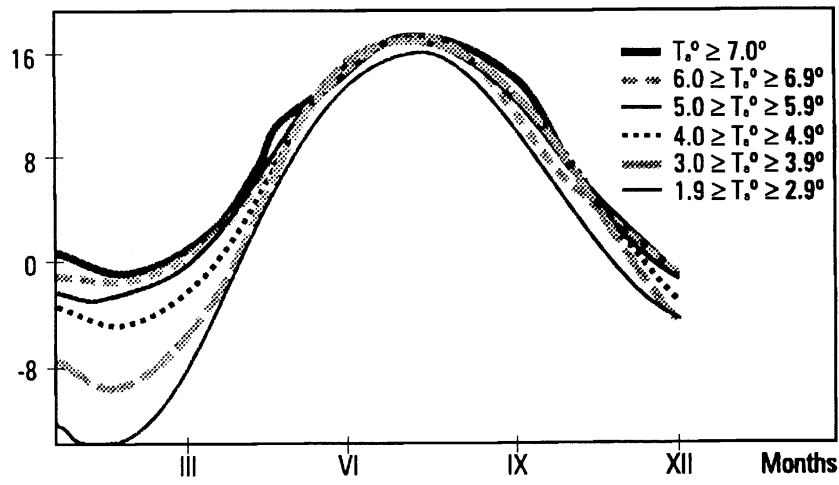

Fig. 6. Average monthly air temperatures with different annual mean temperatures in Estonia lization with climatic (from meso- to micro-climatic) resources include optimization of agricultural techniques, amelioration, fertilization, introduction of new varieties, and so forth.

\subsection{Changes in agroclimate}

The Estonian territory is quite small, and in global climate research we can usually only find average indicators. Based on the literature, we can say that the supposed change in annual mean air temperature lies within the range of 1 to $3^{\circ} \mathrm{C}$ for Estonia. There were no remarkable changes discovered in the time series. Annual average temperature changes were more or less occasional (Karing 1992).

A comparison of the predicted air temperature changes with Estonian local observational time series shows that they are within the limits of air temperature changes in earlier years. From this we can conclude that the supposed global climate changes will not bring about any catastrophic change in temperature. Therefore, within the framework of an expected warming of the climate, the change in the Estonian climatic regime will be observable on the basis of climate element indices determined for earlier years by using the method of time analogues of climate.

In different years the time course of air temperature can greatly differ from the average one. To characterize these climate analogues during the 1866-1995 period, we grouped years into warm and cold on the basis of the average temperature. The average temperature regime was characterized by the years with annual average air temperature, $T_{k}$, within the 4.0 to $4.9^{\circ} \mathrm{C}$ range. The years were evaluated to be cold when $T_{k}$ was 3.0 to $3.9^{\circ} \mathrm{C}$, and very cold when $T_{k}$ was $2.9^{\circ} \mathrm{C}$ or lower. Warm years were the years when $T_{k}$ was 5.0 to $5.9^{\circ} \mathrm{C}$, and very warm years were ones when $\mathrm{T}_{\mathrm{k}}$ was $6.0^{\circ} \mathrm{C}$ and higher. Variations in air temperature by years were categorized into groups as shown in Fig. 6. It is clear that, regardless of large differences in $T_{k}$, the curves are quite similar. It is worth mentioning that the difference in air temperature from average values is most remarkable during the winter months. The higher $T_{k}$ was, the warmer the winter. During spring, monthly differences decreased. In summer, air temperature practically does not depend on $T_{k}$. In autumn, the air temperature was higher in warm years.

To quantitatively estimate the heat accumulation near the surface, warmth indices are widely used in agriculture, agricultural meteorology, phenology, and climatology (Davitaja 1964). The warmth index, or degree-days, may be defined as the sum of daily mean air temperatures above $0^{\circ} \mathrm{C}$ or 5,10 , and $15^{\circ} \mathrm{C}$. In Estonian territory the average sum of temperatures 


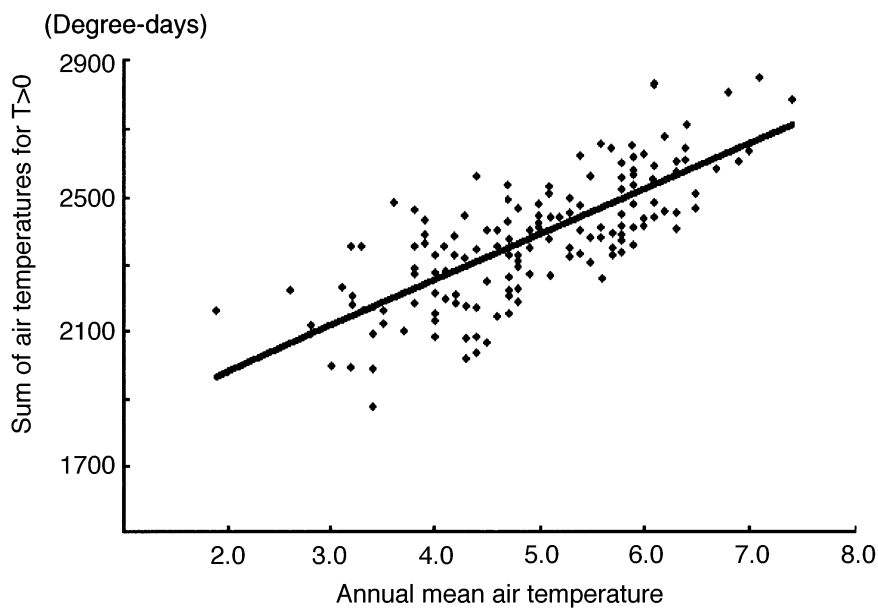

Fig. 7. Relationship between sum $\left(T>0^{\circ} \mathrm{C}\right)$ of air temperatures (warth index) and annual mean air temperature in Estonia

above $0^{\circ} \mathrm{C}$ is 2335 degree-days, and the sums of temperatures above 5,10 , and $15^{\circ} \mathrm{C}$ were 2194,1794 , and 939 degree-days, respectively. The heat accumulation expressed by sums of positive temperatures depends on $T_{k}$ (Fig. 7). Similar to the positive temperature sum in the warm period, the winter conditions were characterized by a negative sum of temperatures. For the period when air temperature was below 0 and $5^{\circ} \mathrm{C}$, the negative sums were calculated to be -534 and -387 degree-days, respectively.

It was found that degree-days serve as good indicators of climate change. According to Karing (1992), the degree-days were calculated as an average for all Estonian meteorological stations over the time span
1807-1990. It was found that the degree-days above 0 and $5^{\circ} \mathrm{C}$ have had a noticeably positive trend (about 1 degree-day $\mathrm{yr}^{-1}$ ) for almost 2 centuries in Estonia (Fig. 8), and from this follows an important conclusion: heat accumulation has increased in early spring in the Estonian area.

The number of days with air temperature above 0 and $5^{\circ} \mathrm{C}$ also notably increased during the period observed (Fig. 9). The observed trends are statistically significant at the $1 \%$ significance level. Corresponding positive trends for the degree-days and number of days with air temperatures above 10 and $15^{\circ} \mathrm{C}$ are not significant. As a consequence, we can conclude that the beginning of spring and the development of nature have shifted to an earlier time in the year.

In conclusion, it can be said that the rise in average temperature has brought about a change in the course of annual temperatures in Estonia, prolonging the total growing season and also the sowing and autumn harvesting periods.

\section{CONCLUSIONS}

The key problem of mankind's response to climate change is the adaptation of agriculture to the changed agroclimatic conditions and resources.

We recommend that plant cultivation be established according to the principle of maximum plant productivity (Tooming 1988). This means that our task is to obtain the maximum achievable yield from each field. Generally speaking, plant cultivation in accordance with the principle of maximum plant productivity will utilize natural resources (soil and climate) not only

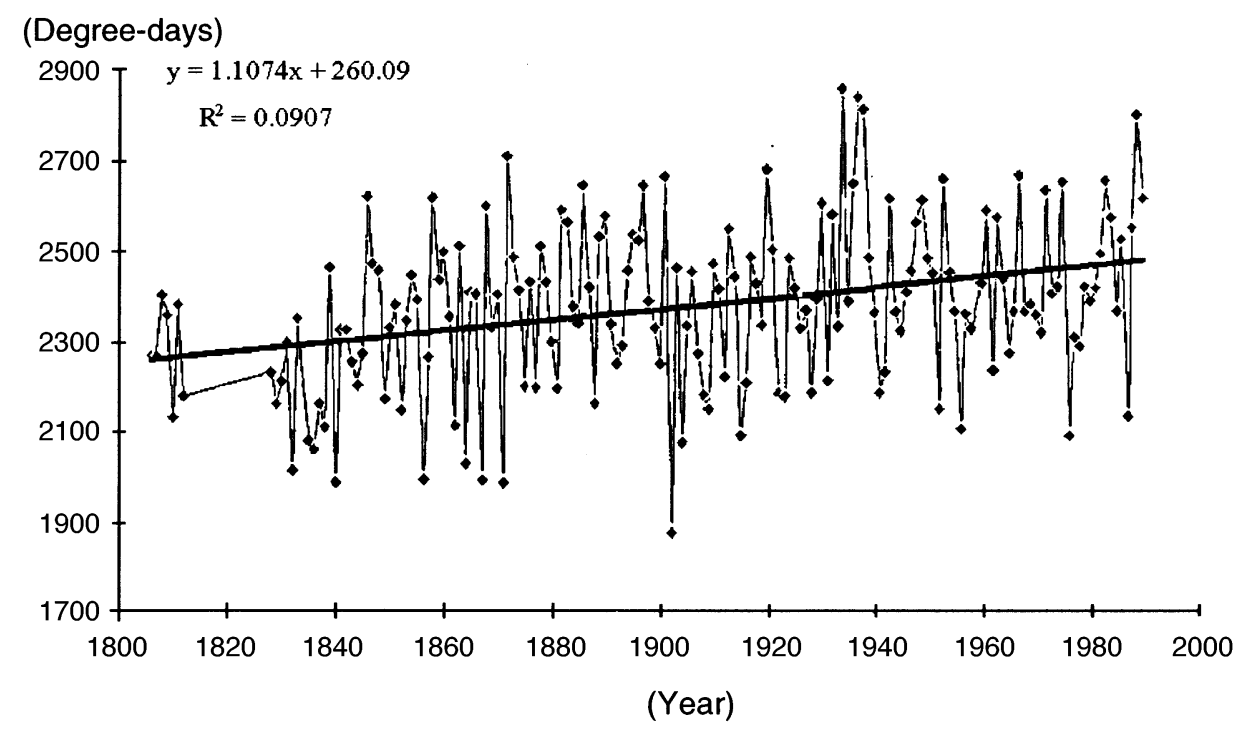

Fig. 8. Degree-days above $0^{\circ} \mathrm{C}$ for the period 1807-1990 in Estonia 


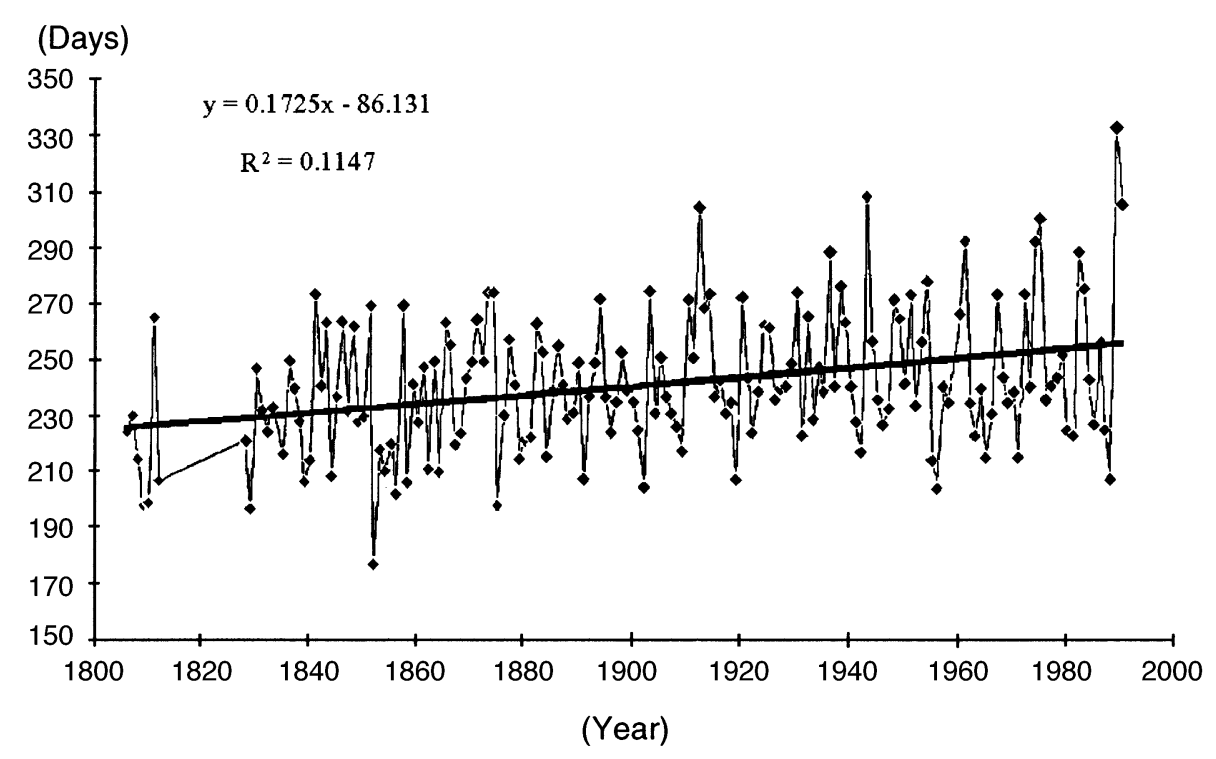

Fig. 9. Number of days with air temperature above $0^{\circ} \mathrm{C}$ for the period $1807-1990$ in Estonia

with maximal productivity in the existing environment but also with maximal efficiency. Natural plants and plant communities are systems that have adapted to the existing climate and all environmental conditions during a long evolutionary process. Their structure and functions are harmonically related and well adapted to the climate and environmental conditions. Field crops have been developed by human activity over a long period of time. Accordance of plant demands with the given climatic and environmental conditions for agricultural crops is the most important precondition for high productivity.

Plant cultivation, according to the principle of maximum productivity, is to a greater or lesser extent vulnerable if the climate changes. With global and regional climate change, the agroclimatic resources will also change. An adaptation of agriculture is needed to provide high productivity of different crops in changed climatic conditions. The following are among the preconditions for the adaptation of agriculture to the changed climate: (1) Recurrent assessment of agroclimatic resources for changed global and regional climate. Generally speaking, an assessment of the new agroclimatic potential of different regions is needed. (2) Prediction of agroclimatic resources for various scenarios of climate change using mathematical models of crop productivity. For example, calculations using the dynamic model POM OD (Sepp \& Tooming 1991) show that potato productivity is most sensitive to changes in spring water storage in soils, shifts in potato sowing time, and growth of precipitation.

After changed climatic resources have been predicted, it is necessary to achieve harmony between plant and crop demands and the new climatic condi- tions. The strategy for such an adaptation of agriculture must include the following: (1) Optimal allocation or agroclimatic regional division of crops considering the climate of the region and optimal use of the changed micro-climate of fields on slopes, valleys, near forests, and so forth to provide maximum productivity of crops. (2) Use of southern species and varieties in the case of increased air temperature and degree-days (for example, in Estonia, greater use of corn, spring wheat, buckwheat, sunflower and so forth). (3) Improvement of plants by breeding with the aim of achieving a better response of plants and crops to the changed climate conditions (Kallis \& Tooming 1974). (4) Improvement of climatic conditions by means of amelioration (for example, numerical experiments using a mathematical model [Tooming \& Karing 1977] show that sprinkling in dry coastal areas and on islands provides substantially higher yields of grasslands). (5) High-quality agrotechnics and yield programming under changed climate conditions; adaptation of nutrient use to the changed climatic conditions; according to the numerical experiments (Karing 1995, Karing et al. 1987), in the case of sprinkling increased quantities of nitrogen fertilizer are needed for cereals and grasslands; the possibility exists for economical use of nutrients in arid coastal and island areas for cereal crops. (6) Elaboration of new methods for crop protection from pests and disease under the conditions of a changed climate. (7) Assessment of the frequency of night frosts under the conditions of changed climate and the proposal of new sowing times due to the vulnerability of different crops, (8) Use of long time series of climatically possible yields, calculated according to models, is urgently recommended for the studies of the impact of 
climate change on crop yields and their statistical distributions.

The general conclusion is as follows: on the basis of the analysis of model yields and field experimental data, the revision of all agricultural sciences against the background of climate change is urgently needed to provide the basis for a new agricultural policy to respond to the conditions of changed climate. The study of soil climate is considered to be particularly important in the studies of micro-climate and its changes.

Acknowledgements. The authors greatly acknowledge the contribution of colleagues Dr J. Kadaja and Mrs Anne J õeveer. The authors are also deeply grateful to Drs T. R. Carter, S. Ahmed, N. Mimura, T. Diaw, and J. Smith for their helpful suggestions.

\section{LITERATURE CITED}

Carter TR (ed) (1996) Global climate change and agriculture in the North. Agric Food Sci Finland 5:222-385

Davitaja FF (1964) Forecast of the provision of warmth and some problems of seasonal development of nature. Gidrometeoizdat, M oscow (in Russian)

Kadaja J, Tooming H (1998) Climate change scenarios and agricultural crop yields. In: Tarand A, Kallaste $\mathrm{T}$ (eds) Country case study on climate change impacts and adaptation assessments in the Republic of Estonia. SEI, Tallinn, p 39-41

Kallis A, Tooming H (1974) Estimation of the influence of leaf photosynthetic parameters, specific leaf weight and growth functions on yield. Photosynthetica 8:91-108

Karing PH (1992) Õ hutemperatuur Eestis (Air temperature in Estonia). Valgus, Tallinn

Karing PH (1995) Practical applications of microclimatic knowledge and information to agriculture. C AgM Report No. 62, WMO/TD No. 726, Geneva
Karing PH, Vartseva SE, Tooming HG (1987) Regulation efficiency of barley crop productivity. Proc All-Union Inst Agric M eteorol 22:73-81 (in Russian)

Keevallik S (1998) Climate change scenarios for Estonia. In: Tarand A, Kallaste T (eds) Country case study on climate change impacts and adaptation assessments in the Republic of Estonia. SEI, Tallinn, p 30-35

Parry M, Carter T (1998) Climate impact and adaptation assessment. Earthscan, London

Parry ML, Carter TR, Konijn NT (1988) The impact of climatic variations on agriculture, Vol. 1. Kluwer Acad Publ, Dordrecht

Penning de Vries FWT (1984) Practical uses of dynamic and explanatory models for simulating crop growth. Wiss $Z$ Humboldt-Univ Berlin. Mat Naturwiss 4:343-346

Roostalu H, Tamm T, Viiralt R, Kevvai L, Valgus T (1996) Potential effects of global climate change on Estonian agriculture. In: Punning J M (ed) Estonia in the system of global climate change. Inst Ecol, Tallinn, p 123-138

Sepp J V, Tooming HG (1991) Productivity resources of potato. Gidrometeoizdat, Leningrad (in Russian)

Tooming HG (1977) Solar radiation and yield formation. Gidrometeoizdat, Leningrad (in Russian)

Tooming HG (1984) Ecological principles of maximum crop productivity. Gidrometeoizdat, Leningrad (in Russian)

Tooming $\mathrm{H}$ (1988) Principle of maximum plant productivity. In: Kull K, Tiivel T (eds) Lectures in theoretical biology. Acad Sci Estonia, Tartu, p 129-137

Tooming H (1993) Evaluation of agrometeorological resources based on the potential productivity of crops. J Agric M eterorol J pn 48(5):501-507

Tooming H, Kallis A (1972) Productivity and growth calculations of plant stands. In: Solar radiation and productivity of plant stands. Estonian Academy of Science, Tartu, p 1-121 (in Russian)

Tooming H, Karing P (1977) Agroclimatic estimation of the potential yield of perennial grasses and the yield shortage due to water deficit. M eteorol Hydrol 2:81-86 (in Russian)

Zhukovsky EE, Sepp J V, Tooming HG (1990) Probabilistic forecast of possible yield. Meteorol Hydrol 1:95-102 (in Russian) 